\title{
Socio-economic Impact of Rural Credit in Northern Vietnam: Does It Differ between Clients Belonging to the Ethnic Majority and the Minorities?
}

\author{
Tran Thi Thanh $\mathrm{Tu}^{1}$, Nguyen Phu Ha ${ }^{1} \&$ Tran Thi Hoang Yen ${ }^{1}$ \\ ${ }^{1}$ VNU University of Economics and Business, Hanoi, Vietnam \\ Correspondence: Tran Thi Hoang Yen, VNU University of Economics and Business, Hanoi, Vietnam. E-mail: \\ yentran.ueb@gmail.com
}

Received: November 30, 2014

Accepted: December 31, 2014 Online Published: April 20, 2015

doi:10.5539/ass.v11n10p159

URL: http://dx.doi.org/10.5539/ass.v11n10p159

\begin{abstract}
The paper evaluates the impact of rural credit program on socio-economic development with emphasis on two classifications of clients at household level: the majority and the ethnic minorities in Vietnam. Our paper utilizes the regression analysis of survey data collected in 10 provinces from the North to the South of Vietnam. The analysis reveals that rural credit poses positive impacts on Vietnamese population living in both rural and remote areas. More specifically, an increased VND 1 million of loan would raise the income by VND 0.249 million. At the same time, it would contribute annually to create 1.548 jobs. Besides, it is worth noting that the effects of income improvement and job creation are strongly determined by household's characteristics, i.e. number of working adults, experience of heads of households, and lending conditions in terms of loan size. In addition, rural credit facilitates the access to more nutrition of food in the minorities. Empirical results support that micro-credit intervention in the ethnic minority community has tendency to focus on job-creation and food nutrition rather than income improvement. The t-tests used in this paper support for the alternative hypothesizes that significantly different impact of rural credit program between two separated groups is reflected in terms of various variables.
\end{abstract}

Keywords: rural credit, socio-economic impact, ethnic minority, ethic majority, targeted national program

\section{Introduction - Credit Programs for the Rural Poor and the Minority Groups}

Since 1997 (Note 1), there have been several significant rural programs enacted with the goal of alleviating rural poverty in Vietnam by providing greater access to financial services to the rural poor. Among those programs, Rural Credit (RR) Project funded by the Organization for Economic Co-operation and Development (OECDs), the Rural Finance (RF) Project funded by the World Bank, the Agency Françoise Development (AFD) Project funded by the France Development Agency are extremely significance in association with the frequent credit channels activated by Vietnam Bank for Social Policy (VBSP) and Vietnam Bank for Agriculture and Rural Development (VBARD). Back in 1996, Vietnam loan market was highly characterized by the entire decentralization and domination of the state owned banks, resulting in the lack of market competition (McCarty, 2001). However, those programs were born as creative solutions to the current status of Vietnam loan market, which aims at making credit more available to borrowers and increasing the access of the rural poor to financial services (World Bank, 2009).

A strong growth in recent years has made Vietnam move up from low to middle-income economy. Meanwhile, a various Government's decisions e.g. No 2685/VPCP-QHQT and No1649/CP-QHQT have been imposed with the purpose of reducing poverty and implementing growth strategy (CPRGS). In addition, the national program for the new province in 2010 has brought about a new phase of development for rural areas in Vietnam. Of all these millennium goals, the most impressive progress was indeed the overall poverty reduction with the rate of "poor" households reduced by 75 percent, from 58.1 percent in 1993 to 14.5 percent in 2008. Meanwhile, food poverty decreased by more than two-thirds, from 24.9 percent in 1993 to 6.9 percent in 2008 (UNDP, 2011).

Over the last fifteen years, the World Bank has participated in RR Project with total budget equivalent to US\$ 513.79 million through three separate components that are the Rural Development Fund (RDF); the Fund for the Rural Poor (MLF), and the Fund for Institution Building and Community Development (Note 2). Over 
the years, Rural Finance Project has been a significant step towards providing loans to more than 1,030,000 households and enterprises. An estimated 436,854 jobs were created in multi-sectors including agriculture, manufacturing and transport. In total, there were $1,275,000$ loans of less than US $\$ 350$, with a $38 \%$ proportion of these going to women (World Bank, 2001, 2009 \& 2013).

In line with the World Bank's projects, AFD has financed 69 projects with the purpose of contributing to agriculture and rural modernization of Vietnam. During 1994-2002, two credit lines of AFD Fund had already been put in place for VBARD to refinance to the Vietnamese farmers. The first line made it possible to grant around 30,000 loans of EU€350 and the second line of EU€1,000 in average. During 2003-2013, the third line equivalent to EU€ 45million was implemented with a period in 20 years with 24,101 loans and approximately 460,000 jobs and the repayment rate was extremely high at 97,4\% ( AFD, 2013). According to the World Bank (2013), nearly one third of the funding went to the poorest regions where located most of ethnic minorities, the Northern Midland and Northern Mountains.

Roughly speaking, in Vietnam, the provision of rural credit to people living remote areas are an acutely conscious effort. This could be seen one of effective methods to the poor alleviation in Vietnam in general and in the rural area in particular. Andrew Wells-Dang (2012) indicated that World Bank's Country Social Analysis (2009) explained credit provision as one of the six areas that contribute to ethnicpoverty alleviation. The author also asserted the positive resultsderived from the collaboration of ethnic minority communities themselves and and local government. Therefore, given the important of micro-finance, this paper will evaluate its empirical impacts on improving human welfare in many aspects such as income increase, job creation, and food access. Besides, we aim at making comparison the differences between the impacts on the rural poor in general and the people living in ethnic minorities.

The paper is structured by 4 parts. Section 2 indicates a general literature review about socio-economic effects of micro-finance on human welfare. Subsequently, the conceptual framework and empirical model are analyzed and constructed in section 3 of the paper. In the next section, by using regression analysis, we illustrate the impacts of rural credit on the rural majority clients and minority clients. At the same time, the t-test will be used to give a clear comparison about the impacts of micro-finance posing on the two different groups of people. The paper is concluded by giving some recognitions and recommendations.

\section{Literature Review}

In most ecological and social sciences, there exists a large body of literatures focusing on the influences of rural credit programs on the poor's livelihood patterns, which reflected by either economic impact in terms of income improvement or social welfare such as education, health, water, sanitation and housing for the poor.

Besides, micro-credit and financial services indeed fuelled the poor's ambitions to come out of poverty (Shimamura \& Cornhiel, 2009). Khandker (2000) studied the effect of income increase on the improved consumption of household members, while Dehejia and Gatti (2005) showed how the income variability can decreases due to financial development. Some researchers assert the role of micro-finance in improving economic well-being (e.g., Imai et al., 2010). By comparison, others believed that the access to micro-credit can relax credit constraints and thereby improve social well-being by increasing expenditure on health and education (Aghion \& Morduch, 2005). Among different types of credit, micro-credit significantly raised farmers "time use for self-employed activities" (Li, Gan, \& Hu, 2011).

Whereas, You (2013) evaluated the causal effect of rural household debt associating child nutrition in the poor northwest of China. Interestingly, only in the short-term could the results from both anthropometric and micronutrient measures of child nutrition show micro-credit loans enable children's health improvement, anemia alleviation and zinc deficiency. Additionally, there were also some findings of the linkage between collateral-free loans and the promotion of basic productive health and family planning of the poor recipients (Amin et al., 1998). A micro-credit program also allowed poor woman to improve their family's conditions, approaching to higher reproductive health, emotional stability of well-being and better family planning (e.g., Ahmed \& Chowdhury, 2001; Khander, 2005; Li et al., 2011). In other words, in some cases microcredit empowers women (Goldberg, 2005).

The impact of rural credit is a subject of controversy. Although proponents think that it reduces poverty and lead to higher employment, higher incomes, and improved education of the borrowers' children, opponents still argue that it has driven poor households into a debt trap, in some cases even leading to suicide (Bateman, 2010). Some researchers tried to find the negative impact of micro-credit programs on child's welfare. Morduch (1999) argued that the usage of micro-credit in household income may increase the need for child labor, resulting in the reduction in the child schooling levels. Survey of Shimamura and Cornhiel (2009) also revealed that credit 
uptake decreases school attendance and lead to delayed school enrollment in Sub-Saharan Africa, Malawi.

In this paper, we not only emphasize on the socio-economic impact of rural credits on the poor but also on the "very" poor group of clients that is ethnic minorities. Although this group constitutes only 13 percent of the Vietnamese population it makes up one third of the poor in Vietnam.

In addition, a various studies over the last decades have paid much attention to analyzing determinants of inequality between the minorities and the majority in terms of wage and earnings. Consequently, the differences in socio-economic characteristics of the communities themselves are the main perceiving factors that affect the level of influences of micro-finance on them (Imai, Gaiha, \& Kang, 2011a; Kang \& Imai, 2011b; Ngo \& Wanhaj, 2012; Van de Walle \& Gunewardena, 2001).

In the Northwest, the programs on poverty eradication have consequently brought about many remarkable outcomes. More particularly, the number of the poor reduced almost 4\%/year compared to 2\%/year in 2000-2004 In the period 2006-2010, the Committee for Ethnic Minority Affairs and the UNDP evaluated that the poverty rate in the Northwest (including Thanh Hoa and Nghe An) was down to $17.36 \%$ in 2006-2010, decreasing $19.05 \%$ compared to 2005 . Of all provinces, Lai Chau and Ha Giang witnessed the sharpest reduction of poverty rate with their figures being at 5\%/year and 7\%/year, respectively. Currently, the rate of the poor households in regards to the new poverty line is $29.5 \%$. Besides, the program involving sustainable poverty reduction was successfully implemented and gains lots achievements in 5 years. During this period, many innovative models have been constructed in 218 villages whereas the program finally supports 30.000 poor households to improve production and investment. As a result, nearly $65 \%$ of them were released from poverty (UNDP, 2010).

Also mentioned by the Committee for Ethnic Minority Affairs and the UNDP in 2010, with regards to Resolution 30a/2008/NQ-CP the poverty alleviation program applied in 44 poor districts in the Northwest was received positive response. So far, the poor people in these districts have received much assistance such as labor, finance and food... Especially, total state capital supply in 2011 reached 3.063 billion VND. Besides, many neighboring businesses had strong commitment in supplementing 1837.68 billion VND to the poor districts during the period 2009-2020 (UNDP \& CEMA, 2010).

The problem of poverty in ethnic minorities has been long regarded as a big challenge in Vietnam. Constituting $15 \%$ of the total population, 53 ethnic minorities account for nearly half $(47 \%)$ of the total number of the poor people in Vietnam and 68\% of extreme poverty (World Bank in Vietnam, 2012). Although the living conditions of ethnic minority groups have improved dramatically since the late $90 \mathrm{~s}$, the proportion of ethnic minorities among poor people increased significantly. Of all ethnics, $66.3 \%$ people are still suffering from tough conditions below the poverty line and $37.4 \%$ below the extreme poverty line in 2010. By contrast, in regards to Kinh people, the poor makes up for only $12.9 \%$ and there are only $2.9 \%$ of them are living below the poverty line in 2010 .

Despite being received a comprehensive assistance from such a variety of programs, according to a survey in 2010, poverty rate in the Northwest mountainous area still remained very high, $60.1 \%$. In addition, the poor especially in ethnic minorities have a large number, accounting for $72.8 \%$. Therefore, the hope of sustainably reducing poverty in the North West in general and the minority groups in particular was still far of our reach.

According to World Banks' Country Social Analysis (CSA): Ethnicity and Development in 2009, the so-called six "pillars of disadvantage" were seen as the main causes that lead to poverty in ethnic minorities. The six factors were (i) less access to education; (ii) more sedentary; (iii) less access to financial services; (iv) low productivity and poor quality of land; (v) market access restriction, and (vi) the stereotypical notions/ethnic prejudice and other cultural barriers (World Bank in Vietnam, 2012). Therefore, it was very obvious that the facilitation of the access to financial services in ethnic minorities in general and poor women in particular plays significant role in terms of economic and social development.

Currently, the supply of microfinance is often divided into two areas, the formal and informal. In the formal sector, the Bank for Agriculture and Rural Development (VBARD), the Bank for Social Policy and the People Credit Fund are overwhelmingly dominated the market, accounting for $90 \%$ market share. The rest area includes (i) NGOs that provides financial services; (ii) the social organizations such as Women Union, Farmer's Union and Youth Union that are able to finance small loans by themselves or implement programs sponsored by international NGOs and the VBARD.

Despite the recently intensively preferred credit and trade policy for the ethnic minorities the impacts of rural credit programs on the ethnic minorities in Vietnam are not fully empirically researched. Thus, the first significance of our study is to introduce the deep concentration on the influence of rural credit on the living conditions of the ethnic minority-client group as a representative for the poorest in Vietnam. Secondly, it 
emphasizes whether it exists the differences in socio-economic impact of rural credit between the majority which represents by Kinh clients, and the minorities which include 53 smallgroups of people.

\section{Conceptual Framework}

Modeling the socio-economic impact of rural credit on the poor begins with credit intervention which is regarded as importance as because it ultimately aims at poverty reduction. As a tool for poverty reduction, the rural poor and of course the poorest are reached by micro-credit and other related services (Dichter, 2007).

According to Ledgerwood (2001), impacts of microfinance fall into three categories including economic, sociopolitical or culture, and personal or psychological. The economic effects aim at changes in economic growth in a region or sector such as income, wealth, spending or business expansion; while socio-political influences may seek a shift in the political economic status of a particular subsector or community. For example, credit programs that target a minority ethnic group may seek impacts in terms of changing power equality between that group and the other local majority groups, or the changing in children's nutrition and education.

Johnson and Rogaly (1997) provided a useful distinction between three sources of poverty that include lack of income, vulnerability to income fluctuations and powerlessness. Corbett (1998) argued that the target of microfinance is to reduce the economic insecurity of poor people rather than raise their income. There were also micro-finance institutions (MFIs) that seek to find whether the credit is used for income-generating activities or for "business purpose". In world literature, there existed a conventional school of thought that impact assessment should be conducted both before an intervention and after intervention, and it is followed by three phases: first, a baseline study establishing some controls at the beginning of the credit programs, then an interim or midterm impact assessment, followed 18 months or 2 years later by the final assessment (Ledgerwood, 2001).

With respect to the methods of impact assessment, most researchers in the field used multiple methods that combine qualitative and quantitative approaches (Hulme, 1995; Carvallho \& White, 1997). Others used "some form of quasi experimental design" along with either linear regression or multivariate statistical analysis, and the recommended sample size is about 500 for effective use of control variables, and an interval of 18 to 24 months between data collection rounds for longitudinal analysis (Gaile \& Foster, 1996). McCall and Simmons (1969) proposed some key criteria in terms of the intensively structured observation, triangulation, open-endedness regarded as fundamental characteristics of qualitative approaches. Meanwhile, the authors regarded predesigned and pretested questionnaires in the light of experimental methods, quasi-experimental methods, and non-experimental methods as fundamental attributes to quantitative approaches with econometrics as a statistical technique. In addition, the choice of unit analysis in terms of users and non-users are also highly recommended.

\section{Methodology and Model}

In the logical framework of the paper, the authors propose a model for impact analysis of rural credit intervention on the socio-economic conditions of the poor, which is adapted from the impact model used by Boonperm, J. et al., (2013). In this model, let $\Delta y_{i t}$ be the outcome variables of interest at household level, for instance, changes in income, changes in working hours (job creation), or changes in daily food nutrition for the borrower $(i)$ in time $t(t=2013-2011=2$ years $), \quad \alpha_{i}$ be a separate intercept set up for each household, $x_{i t}$ be a set of repressors. We then represent the household-level fixed- effect model in the following equation (1).

$$
\Delta y_{i t}=\alpha_{i}+\Delta x_{i t} \beta+\varepsilon_{i t}
$$

Repeated cross section data is constructed by using data collected in survey project supported by Vietnam National University (VNU) at the end of 2011 and that of 2013. At this point, our paper is faced with a problem of limited information available on non-borrowers and borrowers. With aim at constructing samples that reflect characteristics of the whole population, the first criteria was diversified locations of borrowers, ten provinces, i.e. three in the north, four in the central \& highland, and three in the south (Note 3) were then randomly selected. Between 2011 and 2013, two surveys interviewed more than 1400 households; in which one third of them were in the ethnic groups. The experts faced with problems arising in the second survey when approximately one third of the first survey's clients had been out of credit programs due to various reasons, and the rest two third were actually re-interviewed. According to the data report of UNDP (2010), the ethnic minorities represent approximately 30 percent of the poor, so in our collected data, two separate samples were constructed with the size equivalent to 209 and 639 respondents respectively.

\section{Result Analysis}

Table 1 shows descriptive statistics on variables used in measuring the impact of the rural credit with the mean values and standard deviations for both the majority and the minorities. As noted above, the minorities are substantially poorer than the majority whether measured by the monthly income change per household (VND 
0.354 million vs. VND 2.939 million) or job-creation per household (101 working hours vs. 491 working hours). However, they are likely to be more frequently access to medical services $(0.78$ vs. 0.86$)$ and have more improved food nutrition ( 0.66 vs. 0.77 ). The important point is that two groups of borrowers differ in some socio-economic conditions.

Table 1. Descriptive statistics on variables used in the analysis

\begin{tabular}{|c|c|c|c|c|}
\hline & \multicolumn{2}{|c|}{ Majority-clients } & \multicolumn{2}{|c|}{ Minority-clients } \\
\hline & Mean & Std. dev. & Mean & Std. dev. \\
\hline \multicolumn{5}{|l|}{ Independent and instrumental variables } \\
\hline \multicolumn{5}{|l|}{ (client's characters and lending conditions) } \\
\hline Age of head of household (in years) & 45.93 & 12 & 48.27 & 12.57 \\
\hline Head of household is female (yes $=1$ ) & 0.66 & 0.475 & 0.55 & 0.49 \\
\hline Number of working adults in household & 4.74 & 1.69 & 4.22 & 1.49 \\
\hline Experiences of head of household in business/self-sufficient sector & 9.92 & 3.04 & 10.92 & 9.68 \\
\hline Increase in the loan amount in 2011-2013 & 17.59 & 2.78 & 8.929 & 5.420 \\
\hline Using credit for the first time (yes $=1$ ) & 0.88 & 1.15 & 0.60 & 0.51 \\
\hline Collateral (yes $=1)$ & 0.39 & 0.48 & 0.57 & 0.49 \\
\hline Duration of loan & 2.93 & 1.14 & 1.04 & 0.76 \\
\hline \multicolumn{5}{|l|}{ Dependent variables } \\
\hline Income change in 2011- 2013 (million VND) & 2.939 & 3.670 & 0.354 & 2.195 \\
\hline Working hours change in 2011-2013 & 491 & 843 & 101.68 & 208.199 \\
\hline Household access to medical services (yes $=1$ ) & 0.78 & 0.429 & 0.86 & 0.35 \\
\hline Food nutrition in 2011- 2013 & 0.66 & 0.47 & 0.77 & 0.41 \\
\hline
\end{tabular}

Source: Based on data from the survey of Vietnam National University as of 2011 and 2013

Table 2 shows the results of Eq. (1) which measures the effects of rural credit on the income changes, job-creation, access to medical services, and food nutrition of the majority and the minorities. The other repressors include a set of variables that include characters of borrowers as gender, experience, and age of the head of household, numbers of working adults in the households, and lending conditions. As a consequence, the result indicates:

First, regarding the impact of rural credit on the income improvement of the majority, it is reflected that an increased VND 1 million of rural credit would raise people's income by VND 0.249 million. Similarly, an increase of one year in age of head of household would raise VND 0.109 million in income. In the meantime, there is no evidence to show that rural credit has positive impact on the income change among the ethnic minorities. Second, it is drawn from the regression analysis that the number of working adults in the household, working experiences of head of household, and the loan amount have positive correlation to the job creation among the ethnic majority in Vietnam, i.e.an increased VND 1 million of loan would contribute annually to create 1.548 jobs $(0.129 \times 12)$. By contrast, the same amount of increase has much stronger effect on the minorities, creating nearly 7 times of the number created jobs with its figure being at 10.116 jobs $(0.843 \times 12)$. Third, there are evidences that age of head of household is fairly significant for access to medical services among the majority. However, it is not true to the case of the minorities. Besides, despite having negative relationship with access to medical services among Vietnamese majorities, the positive change in experiences of head of household enable higher health care assess among the rest group of people.

It is important to note that reasons underlying the improvement of access to medical services are likely to be rural credit intervention. Finally, the three variables including using rural credit for the first time, duration of the loan, number of working adults play a great role in improve food nutrition within the majority group. Loan amount increase and experience of head of the household, by comparison, have strong effect on the food quality of the minorities. 
Table 2. The impact of rural credit on household current income, job-creation, access to medical services, and food nutrition

\begin{tabular}{|c|c|c|c|c|c|c|c|c|c|c|c|c|c|c|c|c|}
\hline & \multicolumn{8}{|c|}{ Majority clients } & \multicolumn{8}{|c|}{ Minorities } \\
\hline & \multicolumn{2}{|l|}{$\begin{array}{l}\text { Income } \\
\text { change }\end{array}$} & \multicolumn{2}{|c|}{ Job creation } & \multicolumn{2}{|c|}{$\begin{array}{l}\text { Access to } \\
\text { medical } \\
\text { services }\end{array}$} & \multicolumn{2}{|c|}{$\begin{array}{l}\text { Food } \\
\text { nutrition }\end{array}$} & \multicolumn{2}{|c|}{$\begin{array}{l}\text { Income } \\
\text { change }\end{array}$} & \multicolumn{2}{|c|}{ Job creation } & \multicolumn{2}{|c|}{$\begin{array}{l}\text { Access } \\
\text { medical } \\
\text { services }\end{array}$} & \multicolumn{2}{|c|}{$\begin{array}{l}\text { Food } \\
\text { nutrition }\end{array}$} \\
\hline & $\begin{array}{l}\text { Co-ef } \\
\text { ficie } \\
\mathrm{nt}\end{array}$ & $\begin{array}{l}\text { p- } \\
\text { Val } \\
\text { ue }\end{array}$ & $\begin{array}{l}\text { Co-ef } \\
\text { ficie } \\
\mathrm{nt}\end{array}$ & $\begin{array}{l}\text { p- } \\
\text { Val } \\
\text { ue }\end{array}$ & $\begin{array}{l}\text { Co-ef } \\
\text { ficie } \\
\text { nt }\end{array}$ & $\begin{array}{l}\text { p- } \\
\text { Val } \\
\text { ue }\end{array}$ & $\begin{array}{l}\text { Co-ef } \\
\text { ficie } \\
\mathrm{nt}\end{array}$ & $\begin{array}{l}\text { p- } \\
\text { Val } \\
\text { ue }\end{array}$ & $\begin{array}{l}\text { Co-ef } \\
\text { ficie } \\
\mathrm{nt}\end{array}$ & $\begin{array}{l}\text { p- } \\
\text { Val } \\
\text { ue }\end{array}$ & $\begin{array}{l}\text { Co-ef } \\
\text { ficie } \\
\mathrm{nt}\end{array}$ & $\begin{array}{l}\text { p- } \\
\text { Val } \\
\text { ue }\end{array}$ & $\begin{array}{l}\text { Co-ef } \\
\text { ficie } \\
\mathrm{nt}\end{array}$ & $\begin{array}{l}\text { p- } \\
\text { Val } \\
\text { ue }\end{array}$ & $\begin{array}{l}\text { Co-ef } \\
\text { ficie } \\
\mathrm{nt}\end{array}$ & $\begin{array}{l}\text { p- } \\
\text { Val } \\
\text { ue }\end{array}$ \\
\hline $\begin{array}{l}\text { Independe } \\
\text { nt and } \\
\text { instrument } \\
\text { al } \\
\text { variables }\end{array}$ & & & & & & & & & & & & & & & & \\
\hline $\begin{array}{l}\text { Age of } \\
\text { head of } \\
\text { household } \\
\text { (in years) }\end{array}$ & 0.109 & $\begin{array}{l}0.0 \\
04\end{array}$ & 0.077 & $\begin{array}{l}0.0 \\
52\end{array}$ & 0.096 & $\begin{array}{l}0.0 \\
17\end{array}$ & 0.051 & $\begin{array}{l}0.1 \\
99\end{array}$ & $\begin{array}{l}-0.06 \\
2\end{array}$ & $\begin{array}{l}0.3 \\
32\end{array}$ & 0.001 & $\begin{array}{l}0.9 \\
80\end{array}$ & $\begin{array}{l}-0.19 \\
1\end{array}$ & $\begin{array}{l}0.0 \\
9\end{array}$ & $\begin{array}{l}-0.03 \\
0\end{array}$ & $\begin{array}{l}0.6 \\
03\end{array}$ \\
\hline $\begin{array}{l}\text { Head of } \\
\text { household } \\
\text { is female } \\
(\text { yes }=1 \text { ) }\end{array}$ & 0.050 & $\begin{array}{l}0.1 \\
88\end{array}$ & $\begin{array}{l}-0.02 \\
0\end{array}$ & $\begin{array}{l}0.6 \\
11\end{array}$ & 0.034 & $\begin{array}{l}0.3 \\
86\end{array}$ & 0.042 & $\begin{array}{l}0.2 \\
82\end{array}$ & $\begin{array}{l}-0.00 \\
1\end{array}$ & $\begin{array}{l}0.9 \\
93\end{array}$ & $\begin{array}{l}-0.00 \\
3\end{array}$ & $\begin{array}{l}0.9 \\
29\end{array}$ & -0.09 & $\begin{array}{l}0.9 \\
03\end{array}$ & $\begin{array}{l}-0.02 \\
0\end{array}$ & $\begin{array}{l}0.7 \\
17\end{array}$ \\
\hline $\begin{array}{l}\text { Number } \\
\text { of } \\
\text { working } \\
\text { adults in } \\
\text { household }\end{array}$ & 0.056 & $\begin{array}{l}0.1 \\
26\end{array}$ & 0.128 & $\begin{array}{l}0.0 \\
01\end{array}$ & 0.014 & $\begin{array}{l}0.7 \\
15\end{array}$ & 0.106 & $\begin{array}{l}0.0 \\
06\end{array}$ & 0.326 & $\begin{array}{l}0.0 \\
00\end{array}$ & $\begin{array}{l}-0.01 \\
3\end{array}$ & $\begin{array}{l}0.7 \\
36\end{array}$ & 0.102 & $\begin{array}{l}0.1 \\
50\end{array}$ & 0.071 & $\begin{array}{l}0.2 \\
04\end{array}$ \\
\hline $\begin{array}{l}\text { Experienc } \\
\text { es of head } \\
\text { of } \\
\text { household } \\
\text { in } \\
\text { business/s } \\
\text { elf-suffici } \\
\text { ent sector }\end{array}$ & 0.050 & $\begin{array}{l}0.1 \\
88\end{array}$ & 0.086 & $\begin{array}{l}\mathbf{0 . 0} \\
\mathbf{3 0}\end{array}$ & $\begin{array}{l}-0.02 \\
3\end{array}$ & $\begin{array}{l}0.5 \\
69\end{array}$ & 0.080 & $\begin{array}{l}0.0 \\
46\end{array}$ & $\begin{array}{l}-0.02 \\
8\end{array}$ & $\begin{array}{l}0.6 \\
38\end{array}$ & 0.070 & $\begin{array}{l}0.0 \\
51\end{array}$ & 0.171 & $\begin{array}{l}0.0 \\
11\end{array}$ & 0.167 & $\begin{array}{l}0.0 \\
02\end{array}$ \\
\hline $\begin{array}{l}\text { Increase } \\
\text { in the loan } \\
\text { amount in } \\
2011-2013\end{array}$ & 0.349 & $\begin{array}{l}0.0 \\
00\end{array}$ & 0.129 & $\begin{array}{l}\mathbf{0 . 0} \\
\mathbf{0 2}\end{array}$ & 0.028 & $\begin{array}{l}0.4 \\
89\end{array}$ & 0.068 & $\begin{array}{l}0.0 \\
93\end{array}$ & 0.220 & $\begin{array}{l}0.0 \\
01\end{array}$ & 0.843 & $\begin{array}{l}\text { 0.0 } \\
00\end{array}$ & 0.079 & $\begin{array}{l}0.2 \\
70\end{array}$ & 0.613 & $\begin{array}{l}0.0 \\
00\end{array}$ \\
\hline $\begin{array}{l}\text { Using } \\
\text { rural } \\
\text { credit for } \\
\text { the first } \\
\text { time } \\
(\text { yes }=1)\end{array}$ & 0.040 & $\begin{array}{l}0.2 \\
79\end{array}$ & 0.021 & $\begin{array}{l}0.5 \\
86\end{array}$ & 0.181 & $\begin{array}{l}0.0 \\
00\end{array}$ & 0.097 & $\begin{array}{l}0.0 \\
13\end{array}$ & 0.107 & $\begin{array}{l}0.0 \\
87\end{array}$ & $\begin{array}{l}-0.02 \\
4\end{array}$ & $\begin{array}{l}0.5 \\
10\end{array}$ & $\begin{array}{l}-0.08 \\
2\end{array}$ & $\begin{array}{l}0.2 \\
46\end{array}$ & $\begin{array}{l}-0.04 \\
4\end{array}$ & $\begin{array}{l}0.4 \\
35\end{array}$ \\
\hline $\begin{array}{l}\text { Collateral } \\
(\text { yes }=1)\end{array}$ & 0.037 & $\begin{array}{l}0.3 \\
18\end{array}$ & $\begin{array}{l}-0.11 \\
6\end{array}$ & $\begin{array}{l}\mathbf{0 . 0} \\
\mathbf{0 3}\end{array}$ & 0.060 & $\begin{array}{l}0.1 \\
33\end{array}$ & $\begin{array}{l}-0.05 \\
3\end{array}$ & $\begin{array}{l}0.1 \\
78\end{array}$ & 0.315 & $\begin{array}{l}0.0 \\
00\end{array}$ & $\begin{array}{l}-0.06 \\
3\end{array}$ & $\begin{array}{l}0.1 \\
05\end{array}$ & 0.070 & $\begin{array}{l}0.3 \\
43\end{array}$ & 0.051 & $\begin{array}{l}0.3 \\
83\end{array}$ \\
\hline $\begin{array}{l}\text { Duration } \\
\text { of loan }\end{array}$ & 0.030 & $\begin{array}{l}0.4 \\
50\end{array}$ & 0.095 & $\begin{array}{l}\mathbf{0 . 0} \\
2\end{array}$ & 0.032 & $\begin{array}{l}0.4 \\
31\end{array}$ & 0.147 & $\begin{array}{l}0.0 \\
00\end{array}$ & 0.030 & $\begin{array}{l}0.6 \\
36\end{array}$ & 0.038 & $\begin{array}{l}0.3 \\
15\end{array}$ & 0.012 & $\begin{array}{l}0.1 \\
50\end{array}$ & 0.030 & $\begin{array}{l}0.5 \\
96\end{array}$ \\
\hline $\begin{array}{l}\text { Dependen } \\
\text { t variables }\end{array}$ & & & & & & & & & & & & & & & & \\
\hline $\begin{array}{l}\text { Adjusted } \\
\text { R-square }\end{array}$ & 0.172 & & 0.150 & & 0.09 & & 0.11 & & 0.31 & & 0.75 & & 0.11 & & 0.48 & \\
\hline $\begin{array}{l}\text { Durbin-W } \\
\text { atson stat }\end{array}$ & 1.747 & & 1.663 & & 1.871 & & 1.661 & & 0.875 & & 1.473 & & 2.031 & & 1.584 & \\
\hline F-statistic & 16.321 & & 6.691 & & 4.718 & & 5.300 & & 11.33 & & 76.498 & & 3.113 & & 20.071 & \\
\hline $\begin{array}{l}\text { Prob } \\
\text { (F-statistic } \\
\text { ) }\end{array}$ & 0.000 & & 0.000 & & 0.000 & & 0.000 & & 0.000 & & 0.000 & & 0.002 & & 0.000 & \\
\hline
\end{tabular}

Source: Based on data from Vietnam National University Survey of 2011 and 2013

Table 3 provides results of the t-test with respect to mean comparison between two separated samples of borrowers, which are significant across selected variables at $5 \%$ significant level at $p=0.000<0.05$. Results of the 
t-test support for the alternative hypothesizes that there are significant difference in impact of rural credit program on socio-economic development in terms of income improvement, job-creation, food nutrition, access to medical services, number of working adults, duration of loan, loan amount increase.

Table 3. Independent sample T-test

\begin{tabular}{|c|c|c|c|c|}
\hline & \multirow{2}{*}{ Hypotheses } & \multicolumn{2}{|c|}{$\begin{array}{l}\text { T-test for Equality of } \\
\text { Means }\end{array}$} & \multirow{2}{*}{$\begin{array}{l}\text { Support } \\
\text { Hypotheses }\end{array}$} \\
\hline & & Test & Sig.(2-tailed) & \\
\hline H1: & $\begin{array}{l}\text { There is a difference in the income change among the } \\
\text { majority and the minorities }\end{array}$ & 10.147 & 0.000 & $\sqrt{ }$ \\
\hline $\mathrm{H} 2$ : & $\begin{array}{l}\text { There is a difference in the job-creation among the } \\
\text { majority and the minorities }\end{array}$ & 6.606 & 0.000 & $\sqrt{ }$ \\
\hline H3: & $\begin{array}{l}\text { There is a difference in food nutrition among the majority } \\
\text { and the minorities }\end{array}$ & -3.087 & 0.002 & $\sqrt{ }$ \\
\hline H4: & $\begin{array}{l}\text { There is a difference in access to medical services among } \\
\text { the majority and the minorities }\end{array}$ & -2.994 & 0.003 & $\sqrt{ }$ \\
\hline H5: & $\begin{array}{l}\text { There is a difference in the number of working adults } \\
\text { among the majority and the minorities }\end{array}$ & 3.939 & 0.000 & $\sqrt{ }$ \\
\hline H6: & $\begin{array}{l}\text { There is a difference in the age of head of household } \\
\text { among the majority and the minorities }\end{array}$ & -2.398 & 0.17 & $\mathrm{X}$ \\
\hline H7: & $\begin{array}{l}\text { There is a difference in experience of head of household } \\
\text { among the majority and the minorities }\end{array}$ & -1.480 & 0.139 & $\mathrm{X}$ \\
\hline H8: & $\begin{array}{l}\text { There is a difference in loan amount change adults among } \\
\text { the majority and the minorities }\end{array}$ & 8.593 & 0.000 & $\sqrt{ }$ \\
\hline H9: & $\begin{array}{l}\text { There is a difference in duration of loan adults among the } \\
\text { majority and the minorities }\end{array}$ & 22.202 & 0.000 & $\sqrt{ }$ \\
\hline H10: & $\begin{array}{l}\text { There is a difference in experience of head of household } \\
\text { among the majority and the minorities }\end{array}$ & -2.207 & 0.028 & $\mathrm{X}$ \\
\hline
\end{tabular}

Notes: " $\sqrt{ }$ " means the alternative hypotheses are supported, that there are a difference in impact of rural credit intervention (H1, H2, H3, H4); and in client's characteristics (H5), and in the lending conditions (H8, H9, H10); " $\mathrm{X}$ " means the null hypotheses are true.

\section{Limitation and Future Research}

Despite facing a problem of limited information available on non-borrowers and borrowers, this study has made huge contribution to analyze the determinants and influences of rural credit on the rural poor in Vietnam.

Such an analysis is very important for policy purposes in Vietnam not only because it can serve as a reference for policymakers in influencing numerous credit policy for the poor in Vietnam but also itestablishes the relativeimportance of the varioussocio-economic factors that affects expected outcomes. From which, given that the policymakers can decide whether or not the community members may benefit from the access to rural credit, their effective control of policymakers can be carried out.

The socio-economic impact assessment reveals that rural credit have significantly contribute to the Vietnamese poor in terms of higher income and higher employment opportunities, and food nutrition and health service access. However this research ignores the clarification of the different impacts on female and male in rural areas. Besides, the wider effects of micro-credit on the member of those communities such as political change, child welfare, and have not received much attention.

In addition, the social inputs in terms ofindividual capabilities (knowledge, awareness, health, etc.)would also affect members in the communities. Thus, they can finally influence the results of the analysis. However, those factors are not taken into account in this model.

Therefore, future studies should include above missing issues, expand the sample to have better and comprehensive data and information. 


\section{Conclusion and Recommendation}

The paper identifies the socio-economic impact of rural credit intervention in the two separated groups which represent for the majority and the minority of Vietnam. It can be concluded that our empirical results confirm the positive effects of rural credit programs on improving living conditions of the poor. Nevertheless, each group cites different effects, in which while the majority can slightly improve their income and job creation the minorities witnesses a noticeable improvement in those aspects. In addition, the results also confirm that both characteristics of the majority's household (number of working adults, working experiences of head of household) and the lending conditions (loan size) could contribute to the overall impact of credit intervention on Vietnamese people living in the two areas.

However, the empirical results in this paper support that micro-credit intervention in the ethnic minority community seems to focus on job-creation and food nutrition rather than income improvement. Besides, experiences of head of household in the field of working have positive effect on the access to medical services among ethnic communities whereas head of household plays a certain role in directing or changing awareness towards medical services.

Results of the t-test support for the alternative hypothesizes that the impact of rural credit program on separated groups of households are almost all different.

This paper provides policy implications with respect to lending practice geared toward improving household's living condition in rural poor and particularly for the remote locations. First, most of the poor are self-employed and self-sufficient with insufficient capital and knowledge for agriculture development. In this regard, policy makers and credit providers should setup well-functioning investment projections in relation to encouraging households and intensively motivate businesses in business planning and work skill improvement. Second, poverty reduction and alleviation must be seen as a long-term task, requiring the active roles of the poor households, and a better coordination with a non-profit organization to lend in the mountainous and remote areas.

\section{References}

Agency France Development. (2013). Ex-post evaluation of the third credit line.

Ahmed, S. M., Chowdhury, M., \& Bhuiya, A. (1998). Two studies of health care-seeking behavior and household sanitation practices of BRAC member and non-member households in Matlab, Bangladesh. Working paper number 22, International Centre for Diarheal Disease Research, Bangladesh (ICDDR, B).

Armendariz de Aghion, B., \& Morduch, J. (2005). The economics of microfinance. Cambrige, MA: MIT Press.

Bernaud, C., Bousquet, F., \& Trebuil, G. (2008). Multi-agent simulations to explore rules for rural credit in a highland farming community of Northern Thailand. Ecological Economics, 66, 615-627. http://dx.doi. org/10.1016/j.ecolecon.2007.10.022

Boonperm, J., Haughton, J., \& Khandker, S. R. (2013). Does the Village Fund matter in Thailand? Evaluating the impact on incomes and spending. Journal of Asian Economics 25, 3-16. http://dx.doi.org/10.1016/j. asieco.2013.01.001

Carvallho, S., \& White, H. (1997). Combining the Quantitative and Qualitative Approaches to Poverty Measurement and Analysis: The Practice and Potential. World Bank Technical Paper 336, Washington. DC. http://dx.doi.org/10.1596/0-8213-3955-9

Corbett, J. (1998). Famine and Household Coping Strategies. World Development 16, 1099-1112. http://dx.doi. org/10.1016/0305-750X(88)90112-X

Dehejia, R. H., \& Gatti, R. (2005). Child labor: The role of financial development and income variability across countries. Economic Development and Cultural Change, 53(4), 913-932. http://dx.doi.org/10.1086/428714

Dichter, T. (2007). A second look at microfinance: The sequence of growth and Credit in Economic History. Centre for Global Liberty \& Prosperity, 15, 2-13.

Economic Committee of the National Assembly. (2012). Report on macro economy "From instability to restructuring".

Gaile, G. L., \& Foster. J. (1996). Households, Microenterprises, and Debt. AIMS Brief S. U.S. Agency for International Development, Washington, D.C.

Hulme, D., \& Mosley. P. (1995). Finance against Poverty. London: Routledge.

Imai, K. S., Gaiha, R., \& Kang, W. (2011a). Poverty, inequality and ethnic minorities in Vietnam. International Review of Applied Economics, 25(3), 249-282. http://dx.doi.org/10.1080/02692171.2010.483471 
Imai, K. S., Gaiha, R., \& Kang, W. (2011b). Poverty dynamics and vulnerability in Vietnam. Applied Economic, 43(25), 3603-3618. http://dx.doi.org/10.1080/00036841003670754

Johnson, S., \& Rogaly, B. (1997). Microfinance and Poverty Reduction. London: Oxfarm and ActionAid. http://dx.doi.org/10.3362/9780855988005

Khander, S. (2005). Microfinance and poverty: Evidence using panel data from Bangladesh. World Bank Economic Review, 19, 263-286. http://dx.doi.org/10.1093/wber/lhi008

Khandker, S. (2000). Fighting poverty with micro-credit: Experience in Bangladesh. Washington, DC: World Bank.

Ledgerwood, J. (2001). Microfinance Handbook: An institutional and financial perspective. Sustainable Banking with the Poor. The World Bank.

Li, X., Gan, C., \& Hu, B., (2011). Accessibility to micro-credit by Chinese rural households. Journal of Asian Economics, 22(3), 235-246. http://dx.doi.org/10.1016/j.asieco.2011.01.004

McCall, G. J., \& Simmons, J. L. (1969). Issues in Participant Observations. Reading, Mas: Addison Wesley.

Milford Bateman. (2010). The illusion of poverty reduction. Red Pepper magazine.

Morduch, J. (1999). The micro-finance promise. Journal of Economic Literature, 37(4), 1569-1614. http://dx.doi.org/10.1257/jel.37.4.1569

Nathanael Goldberg. (December 2005). Measuring the impact of Micro Finance, taking Stock of What we know. Grameen Foundation USA. Retrieved 2012-10-06.

Ngo, T. M. P., \& Wanhaj, Z. (2012). Microfinance and gender empowerment. Journal of Development Economics, 99, 1-12. http://dx.doi.org/10.1016/j.jdeveco.2011.09.003

Shimamura, Y., \& Cornhiel, S. L. (2009). Credit Program Participation and Child Schooling in Rural Malawi. World Development, 38(4), 567-580. http://dx.doi.org/10.1016/j.worlddev.2009.11.005

UNDP. (2012). The Sustainable Future We Want. Annual Report 2010/2011/2012-VN.

Vietnam Bank for Social Policy. (2013). Annual Report 2013.

Wells-Dang, A. (2012). Ethnic Minority Development in Vietnam: What Leads to Success. Background Paper for the 2012 Programmatic Poverty Assessment

World Bank. (2009). Based line report for the third rural finance project.

World Bank. (2013). The third rural Finance Project: Final Socio-Economic Impact Assessment Review.

You, J. (2013). The role of micro-credit in older children's nutrition: Quasi-experimental evidence from rural China. Food Policy, 43, 167-179. http://dx.doi.org/10.1016/j.foodpol.2013.09.005

\section{Notes}

Note 1. Vietnam began its financial reforms in the mid-1990s, and its rural finance has recently made a rapid progress. Loans to rural poor gradually are becoming widespread.

Note 2. RDF includes three credit lines: RDF1 which valued at US\$94.69 million was distributed during (1996-2005), RDF2 which valued at US\$165.7 million was distributed during (2003-2008), and RDF3 which valued at US\$175 million was distributed from 2009 to 2013.

MLF includes three micro-credit lines: MLF1 which valued at US\$11.06 million was distributed during (1996-2005), MLF2 which valued at US\$24 million was distributed during (2003-2008), and MLF3 which valued at US\$10 million was funded from 2008 to 2013.

Note 3. Research groups selected household borrowers in 3 provinces including Bacgiang, Sonla, and Hungyen which represent those located in the North; 4 including Thanhhoa, Hue, and Quangbinh and Gialai which represent those located in the Central \& Central Highland, and 3 including Gialai, Angiang, Camau, Dongnai which represent those located in the South. Minority ethnic groups are located mainly in Bacgiang, Sonla, Thanhhoa, and Gialai.

\section{Copyrights}

Copyright for this article is retained by the author(s), with first publication rights granted to the journal.

This is an open-access article distributed under the terms and conditions of the Creative Commons Attribution license (http://creativecommons.org/licenses/by/3.0/). 